\title{
Strengthening the Brotherhood of Ethnic Groups Rope Through Sport
}

\author{
Yudo Harvianto \\ Department of Physical Education, Health and Recreation, \\ The Faculty of Education, University of Palangka Raya, \\ Palangka Raya, Indonesia \\ yudo@fkip.upr.ac.id
}

\begin{abstract}
Sport is a human physical activity in various ways he pleases. But this time, the sport is not only used as a community physical activity to nourish the body only but not least in some regions, and even the world makes the sport as an instrument to achieve specific goals. Because the sport is not only contributing to health, but exercise can also contribute to the strengthening of social values in society. The primary purpose of this study is to know about strengthening kinship ethnic groups through sport in the city of Palangka Raya. This research uses a descriptive qualitative approach. Data collection techniques used in this study were 1) observation, 2) interview, 3) focus group discussion (FGD), 4) documentation. The Stages methods in this study were (1) Invention (Pre-stage pitch), (2) Discovery (phase of fieldwork), (3) Interpretation (Phase Data Analysis), (4) Explanation (finalized). The results showed that). Sports activities serve to introduce the general public to the Batak culture overseas. b). Sports activities are used as drug homesick. c). More results from sporting activities obtained funds used for other activities d). Sports activities act as friendship among fellow students Batak on the ground overseas. e.) As a means of students to join the community or clan Punguan Batak.
\end{abstract}

Keywords: Tali brotherhood, ethnicity, sports

\section{INTRODUCTION}

Sport is a human physical activity in various ways he pleases. It is undeniable that men are necessarily required the sport in his life. For the exercise, people will get the benefits needed by him. Ranging from an increased immune from attack disease, and practice can also make a person's body to be fit. Many do not know the importance of sports in life to keep in shape. Because regular exercise and routine will make and keep the body fit.

Physical fitness is a condition of a person's body to perform an activity or physical activity without experiencing significant fatigue. And can perform well in the next activity. The above explanation is supported by the notion of sports under the Act, that exercise is any activity that systematically to encourage, nurture, and develop the potential for physical, spiritual, and social.

But this time, the sport is not only used as a community physical activity to nourish the body only but not least in some regions, and even the world makes the sport as an instrument to achieve specific goals. Because the sport does not only contribute to health but also exercise can also provide one of them in the social values and culture of a tribe. Every human being is an individual who has unique, primarily if the individual is located in the community of ethnic groups different. Each ethnic group has its cultural diversity. Wherever they are, in large numbers, they will seek to preserve the cultural renaissance customs.

According to Verhelst (in reference [1]) defines culture are aspects of life be it knowledge, skills, exceptional food and clothing, mentality, values, language, symbols, the social behavior of political and economic, habits and expertise in sports, production and industrial relations, and so on.

Sports contribution to the strengthening of cultural values milia had long since occurred. From the parts of the world, we take the example of a study conducted suppose, reference [2] states that the sport is seen to have an essential role in contributing to teaching language and culture in Finland and can increase feelings of self-esteem and well-being for immigrants there. The results of this study illustrate that sport and culture had a strong relationship for mutual influence. Likewise, research reference [3] says that people of ethnic Ndebele and Shona in Zimbabwe are more fond of the sport of football. For songs and chants by supporters of football in Zimbabwe have been associated or misrepresent the identity of the local tribes.

Lodging in Palangka Raya, there is an interesting fact. That students who have a lineage of Batak make the sport of football as a way to strengthen kinship among them. Every year they hold a two-time football sports competitions. Where in the composition of the committee and all participants of this competition, a prerequisite is that students have the Batak ethnic lineage. For students who do not have a good track of Batak descent from the father or the mother, it is forbidden to enter the competition.

Based on the background that researchers will research, "Strengthening of Brotherhood Tribe strap through Sport in the city of Palangka Raya."

\section{LITERATURE REVIEW}

\section{A. Sports}

Sport is a series of motion exercise regular exercise and planned to preserve motion (which means sustaining life) and improve the ability of motion (which means improved quality of life) [4]. 
muscle, and motor development to produce the maximum movement skills following the desired motion pattern.

So when it is inferred from the sense of the above, the sport is everything human physical activity conscious and planned to maintain and increase the potential for such a person's physical health.

Besides, that exercise is not only made to maintain a healthy body but can also be used as a tool for strengthening the values of buadaya clan. According to research results reference [9] says that in the West, the sport used as a means to achieve social goals. Common objectives in the form of development programs broadly as peace, human rights, and the fight against HIV/AIDS.

While based on research, as suggested by the reference [2] states that Sports are seen to have an essential role in teaching language and culture in Finland and can increase feelings of self-esteem and well-being for immigrants there.

So the conclusion of several experts and the above results that the sport is a physical activity that people consciously to improve and maintain physical fitness. Not only was that exercise could also as a tool for strengthening the values of the culture of a tribe.

\section{B. Tribes}

According to reference [10], the tribe is the tribe of specific social and ascriptive nature (present at birth), which is the same type by age group and gender. Indonesia, the nation with many ethnic groups, and according to statistics, nearly 300 ethnic groups. Each tribe had its customs, behavior patterns, and different norms. However, diverse this nation can integrate into a country of Indonesia to achieve a just and prosperous society.

Indonesia said as a multiethnic state because it consists of various tribes. Each tribe in Indonesia has a culture different from one another. Differences can be seen in daily habits, art, kinship, beliefs, and other customs. According to Verhelst in reference [1] defines culture are aspects of life be it knowledge, skills, unique food and clothing, mentality, values, language, symbols, the social behavior of political and economic, habits and expertise in sports, production and industrial relations, and so on.

Meanwhile, according to reference [11] stating that every culture has norms or rules that govern each social life so that it will create an environment and different individual characters. This is what causes individuals to have characteristics that correspond to the culture.

Background of the differences that make each tribe in Indonesia has unique and distinctive characteristics not shared by other tribes. The uniqueness and features of a tribe will be attached to the individual from the tribe and will be continuously preserved by generations of ancestors to future generations.

If we look, the real ethnicity will refer to the character owned by certain ethnic groups. When we discuss ethnicity, then we can not separate it from the discussion of culture, race, or tribe concerned. The general view says that the values, attitudes, norms shown by the individual of a particular cultural tribe, will be a typical ethnic individual
Then explain again about the physical factor or organic biologics by reference [8] states that "physical factor is related to offspring, including anatomical structures, physiological, muscle function, and its development aid sports achievements." It can be seen that movement abilitie 
concerned where it came from. The typical behavior comes from a culture that has been inherited from one generation to the next. Because that's what makes an individual's behavior is typical of the tribe.

Reference [12] states that the personality in humans can be influenced by culture, this effect can be explained in the context of human personality individuality, assertiveness toward self-control, and situational consistency in their cultural context. Another statement said by reference [13], who noted that cultural values could also increase the positive view of ourselves.

\section{METHOD}

This research uses a descriptive qualitative approach. Because this study was to describe and analyze a phenomenon, social activities, events, and ideas individually or in groups. This research was conducted in the city of Palangka Raya in Central Kalimantan province from July October 2019.

In this study, the sample size is not the most important criterion, because in this study with more emphasis on data sources or informants who can provide information following the purpose of research. Informants in this study were college students studying in the city of Palangka Raya, with a lineage of Bapat or Batak tribes' mother. The determination of students who become informants in this research is purposive sampling. The research subjects must be qualified based on specific characteristics related to the particular purpose. From the selection of informants based on the purposive sampling technique, then obtained a total of 32 students study subjects.

The collection techniques used in this study were: 1). Observation, in the activities of this observation, the researchers observed and recorded an object under study. 2). The interview, in this study, is used as data collection techniques fatherly find the purpose of research. Interviews in this study using a structured interview in depth to dig more information. Interviews with the use of a list of questions that had been prepared beforehand. The same question was posed to all the informants were interviewed. 3 ). The documentation, in this case, is done to obtain data and information in the form of books, records, documents, writing numbers, and drawing the form of reports and statements to support the research. 4). Focus Group Discussion (FGD, FGD is a group of people as participants to discuss the results of in-depth interviews. In this activity, they are guided by a moderator who directs participants to discuss topics to have been found.

Data analysis technique: 1). Data Reduction (Data Reduction), reducing means encapsulates data that has been discovered, then choose things that are considered fundamental, while also focusing on things that are deemed necessary. This stage, the researcher collects all the data from the observation, interviews and documentation that has been gained during the research process - data obtained from studies with a detailed written directly and systematically each finished collecting data. The reports need to be reduced, i.e., selecting subject matter under the focus of research to be easy to conclude. Data reduction is also made to facilitate researchers in finding the data that have been obtained when necessary. 2). Presentation of Data (Data Display), presentation of data is the process of systematically compiling information to derive conclusions as research findings and taking action. Presentation of data is done to construct a narrative text of the collection of information obtained from the results of data reduction, to allow it to be concluded. In presenting this data with analysis data that includes the analysis of the results of observation, analysis of the results of documentation and analysis of the interview. 3). Withdrawal of Conclusion (Conclusion Drawing). In this stage, this conclusion provided findings on the results of the analysis/interpretation of data and evaluation of activities, which include the search for meaning as well as explaining the data that has been obtained. The conclusion of qualitative research is a new finding that had not been there. The results could be a description or picture of an object that previously was dim or dark so that after investigation, it became clear. It can be a causal relationship or interactive, hypothesis, theory.

\section{RESULTS AND DISCUSSION}

\section{A. Description of Race}

This activity is carried out from start to finish at the Mini Stadium Palangka Raya University. Usually conducted in March and October each year, so that is held twice a year. The name of this activity is Somba IMMAHAPPA CUP and CUP. This activity is carried out every year since 2012. It is unique from this activity that the whole committee and participants are required to only students who have a Batak ethnic lineage, from Mom or Dad. This activity begins the process of publication of the activities to students who are ethnic Batak. Then, for students who were interested in following, they were required to pay a registration fee in the high enough amount. Once registration was opened, then they were asked to do a technical meeting between the organizers and participants who have signed up.

\section{B. The Social Value of Activities}

Based on data that were collected, the social cost of sports activities conducted by the Community of Batak Students residing in the city of Palangka Raya is presented as follows.

- Introducing variations, especially language Batak language. Because in Batak alone, there are a wide variety of languages such as English Batak Toba, Simalungun Batak, Batak Karo Batak Pak-Pak.

- Introducing the Batak culture. This activity is always carried out in the opening and closing ceremonies. In the event, the ceremony always displayed cultures derived from Batak. As Batak dance using custom clothing Batak. Also, in this event, the organizers always publicize their activities through electronic media, namely TVRI Central Kalimantan. With the hope that customs can Batak is also known by the people of Central Kalimantan. Later in this activity was the fans even came from students who are not having Batak descent, so they came to know about the Batak culture of the ceremony activities. 
- This event was also used as a cure for homesickness, due to the state of the dominant use or customs Batak cultures such as dress and language so as if it were in my hometown. This is what makes a lot of students who Batak tribes participated in the activities either as organizers, participants, and supporters.

- In this activity, participants who join the competition, as well as supporters of the football game, are required to pay a fee as a supporter of the event. Participants registration fee charged while the fans of match tickets. Results of the funds obtained were not only for supporting the activities of the race but also be used for further activities undertaken by the students Batak, such as family and religious activities. So the sports activities in addition to a fellow student relationship in the soil Batak shoreline, but also serve as a way to raise funds for other activities.

- With this event, it makes students Batak located in the city of Palangka Raya has varied additional functions. For in addition to the activities of this race, they usually also do other activities to establish brotherhood among students Batak.

\section{Sport Contributes to Strengthening the Relationship of Brotherhood.}

The sport contributes to strengthening the ethnic Batak kinship of the students who were residing in the city of Palangka Raya. Based on the data obtained, the activities of sports events organized by the students of the Batak ethnic group in the city of Palangka Raya can make them more compact and tightly cooperate. Because in the committee, the activities are not obligated for the particular surname, all students can be a committee of Batak tribes regardless of clan strapped.

This activity can also be used as a forum of friendship among fellows of the Batak students in the overseas. This activity is attended by so many students of Batak Toba, Batak Karo Batak Mandailing, Batak Pak-Pak, and Batak Simalungun.

Besides, via this activity, the students of the same clan who have never met and known can be brought together and introduced. By doing so, they can invite the students to join the community or clan meeting located in the city of Palangka Raya. Also, based on the data obtained, this activity can enhance solidarity among students of Batak in the city of Palangka Raya.

Based on the data, the social value of sports activities conducted by the Community of Batak Students residing in the city of Palangka Raya: a). Introducing the language variation that exists in Indonesia especially Batak language. Because in Batak alone, there is a wide variety of languages such as English Batak Toba, Simalungun Batak, Batak Karo Batak Pak-Pak. b). Introducing the Batak culture. This because this activity is always carried out in the opening and closing ceremonies. In the event, the ceremony is still displayed cultures derived from Batak. As Batak dance using custom clothing Batak. Besides, in this event, the organizers always publicize their activities through electronic media, namely TVRI Central Kalimantan. With the hope that customs can Batak is also known by the people of Central
Kalimantan. Later in this activity was the fans even came from students who are not having Batak descent, so they came to know about the Batak culture of the ceremony activities. c). This event was also used as a cure for homesickness, due to the state of the dominant use or customs Batak cultures such as dress and language so as if it were in my hometown. This is what makes a lot of students who Batak tribes participated in the activities either as organizers, participants and supporters. d). In this activity, participants who join the competition, as well as supporters of the football, are required to pay a fee as a supporter of the event. Participants registration fee charged while the fans of match tickets. Results of the funds obtained were not only for supporting the activities of the race but also be used for further activities undertaken by the students Batak, such as familiarity and religious activities. So the sports activities in addition to a fellow student relationship in the soil Batak shoreline, but also serve as a way to raise funds for other activities. e). With this event, the students of Batak located in the city of Palangka Raya has varied additional functions. For in addition to the activities of this race, they usually also do other activities to establish brotherhood among students Batak. f). The sport contributes to the strengthening the kinship of the students of Batak ethnic residing in the city of Palangka Raya. Based on the data, the activities of sporting events organized by the students of the Batak ethnic group in the city of Palangka Raya, they can make more compact and tightly cooperate. The committee for conducting the activities is not obligated for the particular surname so that all students of Batak can be a committee regardless of the clan origin. g). This activity can also be used as a forum of friendship among fellow students of Batak of overseas. This is based on the fact that so many students come from a wide range of Batak clans such as Batak Toba, Batak Karo Batak Mandailing, Pak-Pak Batak and Batak Simalungun. h). Besides, via this activity, the students of the same clan who have never met and known can be brought together and introduced. By doing so, the family can invite students to join the community or clan meeting located in the city of Palangka Raya. It is also based on the data obtained that this activity can also enhance solidarity among students of Batak in the city of Palangka Raya.

The above facts describe a pure sport is not only a physical activity community to nourish the body, but exercise can also be used as an activity to reach a particular vision. Among that getting sporting events can also be used as a way to contribute to the social objectives, among which provide to support the purposes and other social activities. In this case, the applied sport as a way to raise funds, to introduce culture to the people on the ground overseas, as well as act as a meeting among fellow students Batak. Every human being is a unique individual, especially when they are in the community of ethnic groups different. Every tribe has an unusual habit with each other,

Contribution to the strengthening of the social value of the sport has long been the case. Even though parts of the world, research conducted reference [2] states that the sport is seen to have an essential role in contributing to teaching language and culture in Finland and can increase feelings of self-esteem and well-being for immigrants there. Likewise, based on what is raised by reference [9], "says that in the 
5) The students of the same clan who has never met and

West, the sport used as a means to achieve social goals. Common objectives in the form of development programs broadly as peace, human rights, and the fight against HIV/AIDS.

Besides, the influence of the social environment will affect them for the move in exercising. With race is the motivation to exercise is increasing, it is supported by a study with cross-cultural conducted by reference [14] which states that specific social and cultural environments can influence participation in sport and physical activity.

From the results of this discussion, illustrates that the social value of sport and culture has a strong relationship for mutual influence.

\section{CONCLUSIONS}

The conclusions of this study, as follows:

1) Sports activities serve as a way to introduce the Batak culture to the masses. Because this activity is always carried out operations of the opening and closing ceremonies. In the event, the ceremony still displayed cultures derived from Batak. As Batak dance using custom clothing Batak. Besides, in this event, the organizers always publicize its activities through electronic media such as local television.

2) Sports activities are used as drug homesick because the prevailing environmental conditions using the culture or customs of dress and language Batak like that as if it were in my hometown.

3) Results of sporting activity funds obtained were not only for supporting the activities of the race but also be used for further activities undertaken by the students Batak, such as familiarity and religious activities.

4) In this activity can also be used as a forum of friendship among fellow students Batak on the ground overseas, because this activity was found so many students who come from a wide range of Batak. known be brought together and introduced. By doing so, they can invite students to join the community or clan Punguan.

\section{REFERENCES}

[1] H. Z. Khairullah and Z. Y. Khairullah, "Cultural Values and Decision Making in China," International journal of business, humanities, and technology, Vol. 3, No. 2, pp. 1 - 12, February 2013.

[2] T. Zacheus, "The Significance of Sport and Physical Activity During the Acculturation and Integration Process of Immigrants in Finland the Experts' view," European journal for sport and society, Vol. 7, No. 2, pp. 155 - 166, 2010.

[3] L. Ncube, "The Interface Between Football and Ethnic Identity Discourses in Zimbabwe," Critical African Studies, Vol. 6, No.2-3, pp. $192-210$, September 2014.

[4] H. Y. S. Giriwijoyo and D. Z. Sidik, Ilmu Kesehatan Olahraga, Bandung: Remaja Rosdakarya, 2012.

[5] A. Khamdani, Olahraga Tradisonal Indonesia, Klaten: PT. Mancanan Jaya Cemerlang, 2010.

[6] D. Rosdiani, Model Pembelajaran Langsung dalam Pendidikan Jasmani dan Kesehatan, Bandung: CV. Alfabeta, 2012.

[7] K. Jonasson, Sport Has Never Been Modern, Gothenburg: Acta Universitatis Gothoburgensis, 2013

[8] A. Mylsidayu, Psikologi Olahraga, Jakarta: Bumi Aksara, 2014.

[9] D. Ekholm, "Sport and Crime Prevention: Individuality and Transferability in Research," Journal of sport for development, Vol. 1, No. 2, pp. 1 - 12, December 2013.

[10] A. Srijanti, H. I. Rahman, and S. K. Purwanto, Pendidikan Kewarganegaraan untuk Mahasiswa, Jakarta: Graha Ilmu, 2009.

[11] Y. Harvianto, "Minat Partisipasi dalam Olahraga Ditinjau dari Suku Bangsa pada Siswa di Kota Palangka Raya," JUPE: Jurnal Pendidikan Mandala, Vol. 4, No. 4, pp. 17 - 30, June 2019.

[12] D. Gungor, M. H. Bornstein, J. D. Leeersnyder, L. Cote, E. Ceulemans, and B. Mesquita, "Acculturation of Personality: A Threeculture Study of Japanese, Japanese Americans, and European Americans," Journal of cross cultural psychology, Vol. 44, No. 5, pp. $701-708$, July 2012.

[13] E. G. Hepper, C. Sedikides, and H. Cai, "Self-enhancement and Selfprotection Strategies in China: Cultural Expressions of a Fundamental Human Motive," Journal of cross-cultural psychology, Vol. 44, No. 1, pp. 5-23, 2013.

[14] R. Weinberg, G. Tenenbauw, A. Mckenzie, S. Jackson, M. Ansheu, R. Grove, and G. Fogarty, "Motivation for Youth Participation in Sport and Physical Activity: Relationships to Culture, Self-reported Activity Levels, and Gender," Journal sport psychology, Vol. 31, pp. $321-346,2000$. 